\title{
- ESSÕES EM CASA: PRÁtiCAS RELIGIOSAS E VARIAÇÃo EM Almas e Angola
}

\author{
Franco Delatorre \\ Universidade Federal de Santa Catarina \\ Florianópolis - SC - Brasil \\ Orcid: 0000-0002-7801-1557
}

\section{Introdução}

Almas e Angola é uma prática religiosa afro-brasileira bastante difundida no estado de Santa Catarina, e a maior parte de seus numerosos templos - chamados terreiros, centros e casas - está localizada em Florianópolis e cidades vizinhas. No presente estudo, a etnografia está concentrada nas chamadas sessões em casa ${ }^{1}$, rituais fora dos terreiros nos quais são invocados espíritos e orixás. Tais rituais são abundantes mesmo entre adeptos que frequentam algum terreiro, mas envoltos em tensão porque omitidos de seus pais e mães de santo. Rituais alhures são desaconselhados ou mesmo proibidos pelos dirigentes dos centros, que alertam sobre a imprevisibilidade das forças espirituais quando invocadas indevidamente (por pessoas e em ambientes alegadamente inadequados). Empiricamente, entretanto, as sessões em casa constituem a religiosidade e a história de Almas e Angola tanto quanto aquilo que é vivido nos terreiros.

Conforme Marc Piault (2003), ao pesquisador cabe rastrear os componentes que estão sendo incluídos ou descartados pelos interlocutores naquilo que denominam sua religião (sejam locais, sejam seres, situações, etc.). Afasto-me, assim, de uma herança intelectual que traz(ia) a dicotomia entre religião e magia, que legitimaria a primeira pelo seu aspecto coletivo, sendo construída como "tradicional", e a segunda pelo âmbito individual, da degeneração/profanação das tradições e, portanto, do 
espúrio (Bastide 1971; Góis Dantas 1988). A partir das sessões realizadas por Mara e por Rita em suas residências, buscarei demonstrar que esses rituais "marginais" permitem compreender, entre outras questões, parte significativa das diferenças, ou das variações intrarreligiosas, entre templos de autodenominação comum - frequentemente apontadas por religiosos e pesquisadores no caso de Almas e Angola.

\section{Sobre Almas e Angola}

A narrativa consagrada entre o povo de santo acerca do surgimento de Almas e Angola em Florianópolis remete à mãe de santo Guilhermina Barcelos, a Mãe Ida, que teria trazido tais práticas religiosas há mais de meio século do Rio de Janeiro onde atualmente Almas e Angola seria inexistente. É reconhecida como a religião afro-brasileira com o maior número de terreiros e adeptos na Grande Florianópolis (Tramonte 2001; Martins 2006; Leite e Pinheiro 2017²). Assim como na Umbanda, Almas e Angola é constituída por influências religiosas ameríndias, do catolicismo, do kardecismo, e de outras religiões afro-brasileiras como a própria Umbanda e o Candomblé. Cristiana Tramonte escreve que a maioria de seus interlocutores afirma que "Almas e Angola é uma mistura de Umbanda com Candomblé" (2001:422). Cardoso e Head argumentam que:

Almas e angola guarda muitas semelhanças com a umbanda, mas, segundo seus praticantes, aproxima-se também do candomblé por causa da influência de seus rituais de reclusão [, de imolação animal] e iniciação. Se a distinção com o candomblé manifesta-se publicamente nos cânticos em português e no próprio conjunto de divindades cultuadas pela almas e angola, para os [...] filhos de santo a diferença está marcada pelo que eles descrevem ser a ênfase na "caridade" em suas práticas religiosas. (2013:269)

Em Almas e Angola são cultuados nove orixás - Oxalá, Iemanjá, Oxum, Ogum, Iansã, Nanã, Obaluaê, Oxóssi e Xangô - e as entidades, os espíritos de humanos outrora vivos ou encarnados. As entidades são classificadas em quatro categorias chamadas linhas: a de pretos e pretas-velhas (espíritos de ex-escravos e de africanos), também chamada linha das almas; a linha de caboclo, que compreende espíritos de indígenas e boiadeiros; a linha das crianças ou bejadas; e a linha do povo de rua, formada por exus e pombagiras ${ }^{3}$. Nesse panteão, há uma hierarquia espiritual, na qual os orixás são tidos como superiores (descritos como as forças da natureza) e a quem as entidades estão submetidas.

Segundo ensinam os religiosos, todos nós somos acompanhados por um coletivo de entes espirituais. Os espíritos acompanham seu filho ou filh $a^{4}$ ao longo da vida e exercem sobre nós os mais variados tipos de influência: desde a transmissão 
de intuições, soluções e ideias, passando dos hábitos mais corriqueiros às decisões mais importantes, e, notadamente, na construção da personalidade - tema de grande importância também a pesquisadores (ver, por exemplo, Segato 1995; Birman 1995; Delatorre 2014). Em Almas e Angola, esse coletivo é denominado de carrêgo de santo, ou simplesmente carrêgo - que não deve ser confundido com seu homônimo negativo, quando a palavra carrego é usada para designar as "feitiçarias" e "magias" que visam ao mal. O carrêgo é composto por pelo menos uma entidade de cada linha (e de no mínimo um exu e uma pombagira, na linha de povo de rua) e mais um casal de orixás, assim perfazendo o mínimo de sete entes espirituais que acompanham uma pessoa ${ }^{5}$.

A corrente mediúnica - ou apenas corrente, forma mais frequente de se denominar o conjunto de adeptos de um terreiro - é composta pelos médiuns de incorporação, cambones e ogãs. Como o nome já sugere, médiuns de incorporação são aqueles cujos corpos materializam a presença dos guias espirituais (orixás e entidades); já ogãs e cambones, em geral, não recebem os guias, mas, respectivamente, tocam os instrumentos musicais e cuidam de entes espirituais incorporados, bem como dos demais médiuns e da assistência ${ }^{6}$. Durante as sessões ou giras, médiuns de incorporação ficam dispostos em filas paralelas no salão principal do terreiro, da qual saem para dançar para seus guias. Ogãs e cambones ocupam seus respectivos cantos nesse mesmo salão, que é separado da assistência por um pequeno muro ou outro tipo de divisória. $\mathrm{O}$ salão abrange ainda o espaço principal: o congá ou altar, para onde se voltam todos os que ali se encontram. É no congá que ficam as imagens sacralizadas em formato piramidal - com Oxalá no topo, seguido dos orixás de cabeça da dirigente do terreiro, e tendo as imagens de Obaluaê e de São Cosme e São Damião nas extremidades da base. Outras imagens, como a de caboclos e de orixás africanos (antropomórficas e de "pele" negra) também podem figurar aí. Flores, velas, copos d'água e oferendas são colocados aos pés dos orixás no congá. É na frente do congá o lugar reconhecido do/a dirigente do terreiro nas sessões, isto é, de pais e mães de santo. São chamadas filhas de santo todas as pessoas que estão sob os cuidados, menos ou mais diretamente, deste/a dirigente.

Todos os filhos de santo passam pelas "etapas evolutivas" (Martins 2006:49), que dizem respeito ao status hierárquico ocupado e cuja ascensão é possível através de rituais de iniciação que envolvem reclusão da neófita e imolação animal (aves). Quem jamais passou por algum desses rituais - as camarinhas ou feituras de santo ${ }^{7}$ ou que recentemente passou a fazer parte da corrente é chamado de anjo de guarda. Todo anjo de guarda deverá passar pelo primeiro ritual de todos, o de batismo, para que receba seu colar de contas brancas e que seja considerado efetivamente membro de Almas e Angola. Os rituais seguintes são o de Bori, de Pai/Mãe pequena, de Mãe/ Pai de santo (quando a pessoa já pode iniciar filhas próprias e abrir seu terreiro). E há, ainda, os rituais que reconsagram esse último título, chamados Reforço de 7, Reforço de 14 e Reforço de 21 anos. 
Ogãs e cambones também deitam, isto é, passam por rituais bastante semelhantes, fazendo com que adquiram um novo status. $\mathrm{O}$ ogã que já passou pelos principais rituais é chamado Ogã Kolofé ou Kalofé. O que chamo de título é denominado coroa pelo povo de santo de Almas e Angola, e diz-se que, a cada ritual de feitura, tanto a médium quanto os seus guias são igualmente $\operatorname{coroados}^{8}$. Uma série de novas exigências, direitos e responsabilidades vão sendo adquiridas à medida que se alcançam novos títulos. O mesmo acontece com os espíritos e orixás de quem os incorpora, pois ganham novos colares, roupas, permissões (as licenças) e reverências nos rituais.

Foi em um terreiro de Almas e Angola situado na parte continental de Florianópolis que conheci Mara e Rita ${ }^{9}$, no ano de 2002. Com o tempo, passei a frequentar as sessões espirituais que faziam em suas respectivas residências. Com o consentimento de Mara, Rita e de seus guias, obtive permissão para fazer registros e realizar entrevistas sobre as sessões em casa, que passaram a ser o tema de pesquisa para o meu trabalho de conclusão de curso em Ciências Sociais (Delatorre 2012).

\section{No barraco, na gaiola}

Os orixás de Rita ficavam sobre sua máquina de costura. Quem é do santo ensina que se deve observar as regras de (in)compatibilidade, kizila, entre forças espirituais e as atividades que caracterizam um determinado espaço. Por isso, não é aleatório que se deixe o que é de exu nas portas que dão para fora de casa, que se evite deixar coisas de santo no quarto em que se dorme, por exemplo. A saleta em que confeccionava roupas para o povo de santo (isto é, para orixás, entidades e membros da corrente mediúnica) foi o único espaço que Rita alegou ter, em seu apartamento, para abrigar as imagens e outros objetos consagrados aos orixás sem que houvesse kizila. Era ali, junto aos carretéis de linha e pedaços de tecido, que Rita acendia suas velas, fazia seus pedidos e suas reverências, batendo cabeça diante de seu pequeno altar.

Ao lado da porta de entrada da casa de Mara havia uma canjira, o espaço destinado ao culto do povo de rua. Aquele assentamento havia sido providenciado pelo seu ex-pai de santo quando Mara era ainda oborizada, isto é, "possuía" Coroa de Bori, e tinha a finalidade de garantir a proteção de sua família que, segundo ela, estava recebendo muita demanda. Desde então, e apesar dos "feitiços" que visavam prejudicar seus parentes, Mara fazia sessões (os rituais de invocação dos guias espirituais) na sala de sua casa, contando com um congá improvisado sobre uma mesa e a ajuda de um parente seu que, nos terreiros e ali, era ogã. Dessas sessões participavam basicamente parentes e amigos de Mara, cerca de dez pessoas ao todo. Como nos terreiros de Almas e Angola, primeiramente eram invocados alguns orixás e, após um breve intervalo, era chamada uma das quatro linhas de entidades.

À época da minha pesquisa, Mara e Rita já eram mães de santo, mas apenas Rita continuava a frequentar um terreiro. A coroa de Rita já lhe permitia ter um 
assentamento de exu. No seu caso, não se tratava propriamente de uma canjira que, com proporções diminuídas, como as da casa de Mara, parecem uma grande caixa, com uma portinhola e espaço para os copos de bebidas alcoólicas, cigarros e velas. Rita guardava os segredos de seus protetores no corredor do décimo andar, não muito distante do elevador, discretamente enterrados em um grande vaso de comigo-ninguém-pode. Do alto de seu apartamento, Rita não fazia seus rituais como os de Mara, mas seus guias incorporavam com uma considerável frequência (pelo menos uma vez na semana), sobretudo para alguém que já trabalhava em um terreiro. Sem ogã e com as mesmas consultantes de sempre (todas também do santo: sua filha, sua nora e, eventualmente, seu marido e eu), os santos de Rita baixavam inadvertidamente ou, caso ela estivesse passando mal (sentindo que a presença espiritual estava intensa), ela mesma entoava as cantigas rituais e algum deles se fazia presente.

Quem convivia com Rita dizia não mais se surpreender com a vovó, sua pretavelha, chegando subitamente enquanto ela cozinhava ou assistia à TV; ou com a pombagira Sete surpreendendo ao abrir a porta dos quartos, anunciando sua chegada. A filha e a nora de Rita contam que essas aparições eram mais frequentes nas noites de sábado: antes que saíssem para dançar, alguma entidade vinha impedi-las, alertando sobre os perigos na rua. $\mathrm{O}$ marido de Rita às vezes chegava em casa do trabalho e já sabia da presença desta ou daquela entidade pelo cheiro do cigarro da Sete, ou do charuto do exu, ou do cachimbo da vovó, e pelo cachorro que se encontrava preso num dos banheiros. $\mathrm{O}$ espaço aberto pela retirada dos sofás e da mesinha de centro abrigava as entidades que vinham fumar, beber e conversar, dando conselhos e ensinando sobre os mais diversos assuntos, sobretudo espirituais.

$\mathrm{Na}$ casa de Mara havia mais agito e mais etapas rituais: as pessoas já vinham vestidas de branco, como nos terreiros; fazia-se a defumação do ambiente; apenas alguns vasos com plantas eram retirados da sala, e abria-se as cortinas que revelavam o congá, sobre uma mesa. Ao som dos tambores, faziam-se presentes orixás e outros guias, que também circulavam pela casa e mesmo pelo lado de fora. Tanto Mara quanto Rita residiam no centro da capital, mas as particularidades de suas residências impunham diferenças às sessões. Os rituais, bem como as entidades, adaptavam-se aos respectivos ambientes: na gaiola (como os guias de Rita chamavam seu apartamento) havia regras quanto aos sons e espaços externos, as quais eram distintas e menos rígidas se comparadas ao barraco (a casa) de Mara. Mas, tanto lá quanto acolá, a campainha sempre tocava durante as sessões, fosse por uma vizinha ou um parente desavisado; ao telefone, procuravam pela "dona da casa” - e, numa ocasião, era o próprio pai de santo que precisava falar com Rita. Mesmo que algumas situações tenham sido embaraçosas - como a vez que a mãe de Mara, que até hoje diz "ter pavor dessas coisas de espírito", abriu a porta e se deparou com sua filha vestida de pijama e chupando um bico, incorporada com sua bejada -, ambas as mães de santo ou suas entidades encontravam um jeito de contorná-las e prosseguir com os rituais. 


\section{Porquês e porquês não}

As práticas que venho descrevendo são bastante conhecidas entre o povo de santo de Almas e Angola. Quem não faz sessões em casa já visitou alguma delas ou conhece alguém que as faz. Todavia, essas são (quase) sempre práticas tensas. Entre os praticantes de Almas e Angola, elas geram polêmicas, dissidências e disputas de poder entre irmãos, pais/mães e filhos de santo (o que inclui, é claro, as próprias entidades). Dirigentes de terreiro desaconselham seus seguidores, quando não proíbem expressamente, de fazer sessões em casa ou, ainda antes, de invocar entes espirituais fora do terreiro. Entre os motivos alegados, aponta-se para os perigos de lidar com os maus espíritos (os eguns e quiumbas) que poderiam agir mais facilmente em espaços que não são devidamente protegidos, como são os terreiros. Alega-se, ainda, que tais práticas deslegitimam a própria razão pela qual os terreiros existem. Uma publicação de um pai de santo de Almas e Angola, em sua página pessoal no Facebook, é um exemplo do referido desaconselhamento:

Outro detalhe para refletir: se fosse para incorporar as entidades em casa (ou na casa do consulente), qual a necessidade de existir um terreiro, com tronqueira, congá e corrente mediúnica firmada? Se temos tudo isso num terreiro é porque lá é o lugar da incorporação e do atendimento acontecer. Se pensarmos o contrário - salvo casos de extrema necessidade - vamos fechar os terreiros e abolir os fundamentos da Umbanda, pois tudo isso passa a ser desnecessário.

Nas dezenas de comentários, apenas apoio e exaltações, nenhuma crítica ou opinião contrária.

Nos terreiros ocorrem represálias, sendo uma delas a expulsão, mas o mais comum é que os dirigentes e/ou uma de suas entidades faça um sermão durante uma sessão, diante dos demais médiuns da corrente, abalando a relação pai/mãe-filho e com irmãos de santo. Por essas e outras tensões, quem faz as sessões em casa procura mantê-las em segredo de sua família de santo, ou as revela apenas para quem julga ser de confiança - o que, é claro, nunca é seguro. Durante algum tempo, integrei a corrente de um centro de Almas e Angola, e todos julgávamos saber quais irmãos e irmãs realizavam ou participavam de rituais alhures, ainda que alguns deles não tivessem nos contado ou assumido. É claro que muitas das referidas acusações vinham de pessoas que também baixavam seus guias aqui e ali. As desconfianças eram constantes, e sempre havia fofocas levadas até o pai de santo. Na opinião de Rita, e ainda que ela concorde com o que dizem os dirigentes de terreiros, há ainda outros motivos para que sejam contra as incorporações em casa:

É o seguinte: eles não querem que o filho de santo trabalhe em casa por quê? Porque nenhum pai de santo - com todo o respeito, tá? - nenhum 
pai de santo quer que o filho seja mais do que ele. Que tenha a mediunidade melhor que o pai de santo. E a desculpa que eles dão é que "vocês vão pegar carregação", "vocês não sabem se defender". [...] Tá certo, quando é uma pessoa que não entende, que não tem um verdadeiro conhecimento sobre isso. Mas desde que a pessoa trabalha sério, desde que a pessoa tenha responsabilidade, eu não vejo motivo de por que não fazer uma sessão em casa. Vá que tu precises botar um santo na Terra na tua casa. E tu és proibida por quê? Por quê? [...] (entrevista com Rita, 01/2011)

Ao ser perguntada se deixaria suas filhas de santo, caso viesse a tê-las, trabalharem em casa, ela diz:

Tem gente que não tem noção, Franco. Não tem noção, não sabe separar. Depende do médium. Depende do entendimento do médium. Se for um médium que eu vejo que ele trabalha direito, né? Que não vai ter problema... eu... não tem problema botar um preto-velho na Terra pra atender, num caso de necessidade. Também não é pra qualquer momento, pra qualquer coisa! [...] Não liberar geral, não liberar geral porque se eles não têm conhecimento eles fazem besteira. [...] Depende da situação, porque... sabe-se lá se tu tá passando mal... digamos que tu tens a tua mediunidade e tás te sentindo mal, aí vai "Ah, vou botar um santo na Terra". Sabe-se lá se é o teu santo ou se é um perturbado [um egum] que vem. [...] Nesse ponto eu concordo com o pai de santo em não aceitar que receba entidade em casa, porque muita gente não sabe como se defender, não sabe como se livrar de um perturbado. Ele não tá pronto, ele não sabe como se virar, entendesse? [...] Tem aqueles que tu nunca confia. Por quê? Porque ele leva na brincadeira, ele não leva a sério, ele marmota. Que tem marmotagem. Todo lugar tem [...] Então é por essas questões que os pais de santo não liberam o filho pra receber entidade em casa. (entrevista com Rita, 01/2011)

Destaco não só as tensões, mas igualmente a presença e o dinamismo desses rituais na experiência religiosa desse povo de santo. Há sempre alguém que conta já ter feito, nem que seja por necessidade, ou que conhece pessoas que trabalham com o santo fora do terreiro. Em entrevista, Rita revelou que:

- Ah... muita gente trabalha escondido. [...] As pessoas trabalham escondido dele [do pai de santo]. Todo mundo trabalha, não vem dizer que não trabalha porque trabalha.

- Mas ele deve saber, né? 
- Eu acredito que sim, porque bobo ele não é. (entrevista com Rita, 01/2011)

À dinâmica de acusações menos ou mais veladas, feitas por meio de fofocas e insinuações, somam-se as afinidades ou alianças (grupos de médiuns com confiança mútua e que trabalham com o santo na casa de fulano ou beltrano). Tudo isso é parte das relações de poder que envolvem médiuns de uma mesma corrente e que também ocorre entre terreiros. Em qualquer caso, podem surtir um duplo efeito. Seja qual for o caso, pode haver um duplo efeito. Se, por um lado, pessoas podem vir a ser prejudicadas, seja moralmente, seja devido a sua exclusão do grupo, por outro, esses rumores podem instaurar uma diferença dessa outra pessoa que, por sorte ou por azar, passa a ser vista como poderosa e, portanto, como uma referência espiritual em potencial. Foi esse o caso de Mara. Ela me contou que seus irmãos de santo confiavam nela e em suas entidades, que, por isso, gostariam de ter mais consultas, longe dos limites do terreiro e não mais sob os olhos do pai de santo, e a pressionavam para que ela os atendesse em sua casa, alegando a vantagem de lá haver uma canjira, que faria de sua casa um local espiritualmente seguro. No entanto, a corrente na casa de Mara continuou sendo a mesma, com amigos e parentes. A assistência oscilava entre os próprios médiuns que usufruíam das consultas com as entidades que ali estavam e eventuais conhecidos destes que diziam precisar de ajuda espiritual.

Mas por que fazer as sessões em casa? Qual a diferença de trabalhar com o santo em casa? O que acontece aí? Essas eram as minhas principais perguntas durante a pesquisa. Entre as respostas dadas a mim e as conversas entre os participantes nos rituais, falava-se das já citadas exceções - isto é, dos "casos de extrema necessidade" - e da caridade, tão mencionada nos terreiros, que, dizem, deve ser feita onde e quando for necessária. Porém, com o passar do tempo compreendi que a recorrente fala de que "nem tudo pode ser feito no terreiro" era mais complexa do que parecia ser. Para além de questões de tempo - escasso nos centros, pois há muito mais do que consultas e trabalhos a ocupar o tempo de uma gira -, comentários assim apontavam caminhos para entender tanto as minhas inquietações quanto outras questões transversais.

Fora dos limites do terreiro e do olhar do pai de santo e de suas entidades, outras coisas são possíveis. Regras são desfeitas, explicações são substituídas, segredos são revelados, fronteiras são ultrapassadas. Se, nos terreiros em geral, apenas os guias de quem já fez Coroa de Bori podem dar consultas e vestir roupas de cores, em casa, desde cedo, as entidades de Rita e de Mara - bem como de outros iniciantes, como a filha de Rita - vestiam roupas próprias, fumavam, bebiam e davam consultas. Tão logo começara a falar, após umas poucas incorporações, a pombagira da sobrinha de Mara, que nunca havia participado de um terreiro por proibição de seus pais, passou a dar consultas, fumar cigarros e beber sidra. Nos terreiros, os trabalhos (manipulação de certos conjuntos de elementos para fins diversos) são feitos menos ou mais diretamente sob a observação do/a dirigente e de seus guias, podendo ser vetados de acordo 
com o contexto ritual e as regras do centro. Em casa e alhures, por sua vez, parece haver maior frequência na recomendação e no preparo de trabalhos e oferendas, seja pela médium, seja por uma entidade sua.

As sessões em casa são momentos caracterizados também pelas avaliações de médiuns e de seus guias em relação ao(s) terreiro(s): comparando-os, falando sobre outras experiências e opinando naquilo que acham que seria ou não correto, ético ou aceitável. Espíritos e pessoas também trazem fórmulas rituais e aprendizados novos, propõem explicações e prescrevem comportamentos que podem corroborar ou não o que se havia aprendido e vivenciado nos centros. Lembro-me da preta-velha de Mara ensinando que não se deve girar o corpo de um/a médium iniciante quando algum orixá está baixando. "Isso não se faz!", dizia ela, explicando que quem deve comandar os movimentos do corpo é a própria divindade, já que muitas delas não dançam girando. $\mathrm{O}$ exu de Rita contava como um pai de santo realizava os rituais de feitura sem imolar as aves, extraindo apenas algumas gotas de sangue do pescoço dos animais, deixando-os vivos, portanto, e que, por isso, sua burra não deveria ousar migrar para aquele terreiro. Mara contestava os terreiros, pois, segundo ela, a maioria só permitia aos médiuns de incorporação dançar e fazer concentração aos respectivos orixás de suas cabeças:

O certo é como era lá na Mãe M... [sua primeira mãe de santo], que todo mundo dançava para todos os orixás. Não faz mal dançar pra todos, isso não vai mudar quem é teu pai e quem é tua mãe [de cabeça], não tem nada a ver uma coisa com a outra. A Almas e Angola da Mãe Ida era assim: pra tu ser uma mãe de santo completa, antes disso tu vai ter que receber todos os orixás pelo menos uma vez. Sabias disso? (entrevista com Mara, 01/2011)

\section{Entre casas e Casas}

A presença corporificada de espíritos em casa ou em outros lugares é algo bastante comentado entre o povo de santo e por pesquisadores (Cardoso 2007, 2014; Velho 1994; Hayes 2011; Opipari 2009; Sansi 2013; Delatorre 2014). Os praticantes de religiões afro-brasileiras descrevem a participação cotidiana de orixás e de outros entes espirituais (bons e maus) como atores sociais:

[...] os espíritos são culturalmente reconhecidos enquanto sujeitos - no sentido de terem desejos, serem geradores de ação, e terem uma subjetividade culturalmente reconhecida - intimamente relacionados com seus médiuns, mas de forma alguma pertencentes a estes ou de natureza similar a estes. Seu estatuto de sujeito é necessariamente distinto daquele dos outros sujeitos sociais - vivos ou já mortos - afinal são conhecidos 
como "espíritos", "santos", "entidades", e não como "pessoas" (Cardoso 2009:206).

Essas narrativas são frequentemente marcadas pelo inesperado e pela imprevisibilidade. Seu reconhecimento, no entanto, é feito por meio de índices decodificados dados por quem sabe ou pode percebê-los (gestos, gostos, sons, imagens e ainda outros sinais podem estar em jogo), ou mesmo nas súbitas incorporações como aquelas descritas acima, que se davam com Rita (ver também Cardoso e Head 2013). Por outro lado - e independentemente de vinculações ou não a um terreiro -, essas presenças são igualmente procuradas e invocadas: daí ser comum que os cômodos de uma residência venham a ser "temporariamente redefinidos como espaços rituais" (Cardoso 2007:317).

$\mathrm{Na}$ verdade, falar de possessão entre nós, cidadãos brasileiros, faz parte do nosso feijão-com-arroz. Não é preciso ser espírita, umbandista ou membro de algum candomblé para viver submerso num mundo em que vagam espíritos, em que interferências dos santos e das almas são permanentemente cultivadas. Daí para a possessão é só um pequeno passo. Alguém ser tomado por um espírito, estar sofrendo do encosto de uma alma penada não é uma coisa do outro mundo, com o perdão do trocadilho; faz parte da "ordem natural" das coisas. Em resumo, a possessão como uma forma particular de contato com o sobrenatural é uma referência constante da cultura brasileira (Birman 1983:8).

Nos discursos dos dirigentes de terreiros essas práticas "outras" são postas às margens das "práticas espirituais legítimas": ou seja, aquelas que ocorrem sob a supervisão de pais e de mães que possuem casa de santo. No entanto, empiricamente, a religiosidade do povo de santo está para além das várias formalidades (rituais, hierárquicas, espaciais, etc.) aí existentes, uma vez que as interações de médiuns e espíritos se espalham pelo cotidiano em residências, praias, matas e encruzilhadas. A convivência com o povo de santo torna possível perceber o quanto essas interações, independentemente de serem ou não ritualizadas ou intencionadas, nada têm de marginal. Ao contrário, possuem importância idêntica àquelas vivenciadas nos terreiros, sendo igualmente constitutivas da história e da religião desse povo. As trajetórias religiosas de Mara e de Rita, a exemplo de inúmeras outras, tiveram início a partir de manifestações espirituais que se deram longe de um terreiro. Mara, por exemplo, jamais havia pisado num terreiro nas primeiras vezes em que sua preta-velha chegou em sua casa, causando espanto aos seus filhos e marido. Rita, por sua vez, conta ter buscado o auxílio de uma sobrinha que baixava entidades em casa por conta da doença de sua filha. No entanto, ao chegar lá, disse ela, "foi a minha entidade que baixou e disse que era problema espiritual, e ali eu comecei a me desenvolver"10 (entrevista com 
Rita, 01/2011). Assim, aquilo que os religiosos vivem cotidianamente com os entes espirituais (as manifestações via incorporação, os sonhos, as intuições, uma voz ao pé do ouvido, visões e outras sortes de interações) é parte fundamental do chamado caminho no santo e reverbera, como veremos, para além da esfera individual e das microrrelações.

Lidar com variações é uma constante nos estudos das religiões afro-brasileiras. A heterogeneidade constitutiva dessas religiões resulta, no campo religioso, em debates, disputas e tentativas de normatizações e homogeneizações - papel histórico de algumas Associações e Federações. Do lado acadêmico, tem dificultado o trabalho daqueles que buscam elaborar definições e padrões. Almas e Angola não é exceção àquilo que Goldman denomina "Lei de Herskovits" (2012:273), pois "cada caso é mesmo um caso, e essa lógica polívoca e plural é mais uma demonstração daquilo que talvez possa ser considerada a única lei sociológica [postulada por Melville Herskovits, na década de 1950] jamais isolada nos estudos sobre as religiões de matriz africana no Brasil". A diversidade empírica, que faz com que os terreiros apresentem significativas diferenças entre si mesmo sob uma autodenominação comum é, portanto, algo a ser compreendido, e não preconcebido como falho ou a ser corrigido.

Já na esfera "macro" ou "pública", a dos terreiros, também são muitos os caminhos pelos quais se pode iniciar uma análise. $\mathrm{O}$ "diverso" evidencia-se aqui já no que diz respeito ao nome da religião: "Almas e Angola, Almas de Angola e Almas em Angola, foram algumas das nomeações coletadas" (Tramonte 2001:422, grifo do autor) ${ }^{11}$. Também as autoclassificações variam: afirma-se que Almas e Angola é mais uma religião de matriz africana (ou seja, específica, diferente das demais); que não seria propriamente uma outra religião, mas um ritual da umbanda ou "uma vertente ritualística da umbanda" - e, nesse sentido, religiosos e pesquisadores têm denominado Almas e Angola literalmente de "Ritual" (Martins 2006; Weber 2011; Mützenberg e Weber 2013). Diz-se ainda que é uma "mistura de umbanda e candomblé", como citado no início; que é a "umbanda catarinense" (Martins 2006); e por fim, mais recentemente tem sido chamada de "nação"12 (Martins 2010). Tramonte escreve que:

Almas e Angola está em processo de construção. É bastante complexa sua definição, pois é também recente e praticamente exclusivo em Santa Catarina, único local onde sobreviveu, trazida do Rio de Janeiro por Vó Ida, nos anos 50. Como não há referência de obras de amplitude nacional publicadas sobre o tema, as respostas que obtivemos quando buscamos caracterizar este ritual foram tão diversificadas, que tornou impossível traçar um perfil com características definitivas (2001:422, grifo do autor).

Às diferenças entre os terreiros de Almas e Angola registradas em pesquisas, somam-se as conversas (as fofocas e os fuxicos) do povo de santo, nas quais com- 
param e avaliam a forma com que pais e mães de santo realizam seus rituais. Uma prática que aparece como regra em um terreiro de Almas e Angola pode não ser em outro. Algumas dessas distinções já foram citadas: entidades de pessoas iniciantes que podem ou não usar suas próprias roupas (as chamadas roupas de cor), bem como dar consultas, fumar e beber; e a forma em que são realizados certos rituais, como comentado pelo exu de Rita. Não há, porém, espaço para elencar aqui as inúmeras variações que particularizam alguns grupos de casas ou uma casa em particular. Restrinjo-me, então, a citar algumas delas, tanto as que aparecem na literatura quanto as mais comentadas por adeptos.

O povo de santo e autores como Martins (2006) e Weber (2011) falam de duas Almas e Angola: a de antes e a de depois de Pai Evaldo. Evaldo, antigo filho de santo de Ida, manteve contato com sua mãe de santo após ela se declarar candomblecista e deixar os rituais de Almas e Angola. Ele foi reconhecido como uma liderança religiosa por muitos pais e mães de santo de Almas e Angola ao trazer, com a ajuda de Ida, rituais existentes ou inspirados no candomblé. As "novas obrigações ritualísticas" seriam "as obrigações de Sete, Quatorze e Vinte e Um Anos [...], jogo de búzios, sacrifício de angolistas brancas"13 (Martins 2006:28). Há, assim, terreiros que se dizem mais ortodoxos, que seriam aqueles que fazem "como no começo", e os que adotaram as mudanças trazidas por Evaldo. No âmbito do presente trabalho, não tenho como preocupação associar determinadas práticas a "esta" ou "aquela" Almas e Angola, apenas apontar suas diferenças empíricas. Começo por aquelas que parecem ser as mais discutidas pelo povo de santo, como, por exemplo, a retirada do mel da comida de Oxóssi (kizila deste orixá), uma "iniciativa recente" que estaria sendo copiada por outros terreiros de Almas e Angola (Farias 2008:33). Em Almas e Angola, Oxalá é considerado um Orixá Maior, superior, razão pela qual em alguns terreiros esse orixá é apenas exaltado, mas não incorporado; já em outros terreiros, Oxalá desce. Em algumas casas, a coroa que seria feita para Obaluaê ou para Oxalá é dada a Ogum, ocorrendo assim uma substituição desses orixás na cabeça do/a filho/a. Também os modos de gestão do período da quaresma divergem significativamente entre os centros ${ }^{14}$. Há, ainda, a "polêmica retirada do corte" (Mützenberg e Weber 2013), ou seja, do sangue animal obtido por imolação de aves em rituais de feitura, que até então vinha sendo praticada em poucos terreiros.

Há, por fim, questões polêmicas em torno do cargo de ogã. Nas religiões afro -brasileiras em geral, o papel de ogã é desempenhado exclusivamente por homens que não incorporam. Mas ambas as condições não caracterizam esse cargo em alguns terreiros de Almas e Angola, nos quais há ogãs mulheres e ogãs que revezam entre o tambor e o espaço do salão, onde incorporam seus guias. Para algumas lideranças, que os atabaques sejam tocados por mulheres e que ogãs possam vir a incorporar são situações consideradas absurdas. Os discursos favoráveis à "flexibilidade" do papel de ogã que ouvi frequentemente questionavam "por que não?", ou, então, "que mal tem?". Em conversas com Mara e Rita, ambas defenderam que, às mulheres que 
apresentem o dom para [tocar] os atabaques, deve ser permitido que o façam. Rita, no entanto, não estava convencida de que a incorporação do/a ogã não atrapalharia o desenrolar ritual. Mara dizia que, se algum ogã apresentar o dom da incorporação, não se deve proibi-lo de exercê-la, pois "tem sempre mais de um ogã pra levar a sessão".

Uma lista de diferenças entre terreiros de Almas e Angola seria extensa e não caberia aqui tentar esgotá-las. Como Oliveira registra em sua etnografia, "cada terreiro funciona de acordo com seu líder" (2012:17). Tampouco seria possível explorar as inúmeras razões que ocasionaram uma ou outra mudança. Os trabalhos de Miriam Rabelo (2014) e Carmen Opipari (2009) com o candomblé demonstram como outras religiosidades, espaços, círculos sociais e mesmo as relações com familiares consanguíneos comumente se emaranham na (des)construção de sentidos e de percursos religiosos ${ }^{15}$. Trajetórias individuais e fatores sociais mais amplos imbricam-se para gerar as "misturas" ou influências mútuas que há muito motivam pesquisas sobre religiões afro-brasileiras. Nesse sentido, há dois motores claramente importantes. Em primeiro lugar, as passagens, anteriores ou posteriores, por outras religiões e que acarretam mudanças inter- e intrarreligiosas (como no caso de Mãe Ida). Depois, a produção intelectual em torno das religiões afro-brasileiras, bastante consumida pelo povo de santo, e que incide sobre suas práticas de maneiras diversas (Góis Dantas 1988; Silva 2000; Goldman 2011; Delatorre 2014).

Contudo, são as experiências religiosas fora dos espaços dos terreiros que aqui destaco como fatores indispensáveis para compreender como se dão as variações encontradas nos terreiros de Almas e Angola, com ênfase às chamadas sessões em casa. Não há como precisar as origens de toda e cada diferença observável entre terreiros, mas as sessões em casa evidenciam sua relevância sobre essas práticas religiosas como um todo. Enfatizo esses rituais, mais do que as outras formas possíveis de interação cotidiana com os espíritos, porque eles se configuram como "fenômenos liminoides", nos termos de Victor Turner:

O que mais me interessa na formulação de Sutton-Smith é que ele vê situações liminais e liminoides como cenários em que novos modelos, símbolos e paradigmas surgem, como um solo fértil de criatividade cultural. Esses novos símbolos e construções então retornam aos domínios e arenas "centrais" da economia e da política, suprindo-os com metas, aspirações, incentivos, modelos estruturais e raisons d'être. (2012:223, grifo do autor)

Novos modelos, fórmulas, explicações e proposições surgem nos momentos em que adeptos e seus guias espirituais se juntam não fora, mas às margens dos "domínios centrais" (da religião), cujas normas são postas em evidência, sendo alvos de críticas, debates, reflexões e, consequentemente, de transformação. Afinal, as experiências vividas fora dos terreiros acabam gerando, nas já citadas palavras de Turner, "novos símbolos e construções [que] então retornam aos domínios e arenas centrais". Em 
outras palavras, muito do que vem a ser aprendido fora dos terreiros poderá repercutir dentro dos terreiros, mas, sobretudo, num futuro terreiro no qual se exercerá liderança. Rita, por exemplo, sempre dizia que, caso algum dia dirigisse um centro, suas filhas de santo não seriam obrigadas a usar as enormes (e, segundo ela, trabalhosas) anáguas, tão marcantes nos salões de sua Almas e Angola. O preto-velho de Mara, por sua vez, frequentemente criticava a insistência do uso de imagens de santos católicos (brancos) para substituírem os orixás no congá, bem como a falsa data da libertação dos escravos para se comemorar o dia dos pretos-velhos. Por considerar correto o ensinamento do seu guia e por respeito, Mara passou a fazer as feijoadas de preto-velho não mais no dia 13 de maio, mas em 20 de novembro (dia da Consciência Negra). Já em relação ao altar, afirmou: "Não importa o que vão falar de mim. Falar eles já falam, mesmo. Meus orixás vão ser tudo negão"16 (entrevista com Mara, 01/2011).

Mara alegava seguir os métodos de invocações espirituais de sua primeira mãe de santo, que fazia "a Almas e Angola da Mãe Ida", mas dela se diferenciava ao estabelecer novas práticas, repassadas pelos seus espíritos em um dos cômodos de sua residência. Rita e seus guias criticavam maneiras outras de se realizar rituais, mas sabem - como o sabe Mara - que também serão questionados quando abrirem um terreiro em que as mulheres poderão se vestir de outra forma. Questionar a diferença de padrões enquanto promovem inovação são dois lados de uma mesma moeda nessas práticas religiosas, algo típico nos discursos sobre tradição (Hobsbawm \& Ranger 1984). Inevitavelmente, Rita e Mara verão suas regras questionadas ao modificarem calendários, vestimentas, significados e símbolos em seus (prometidos) terreiros. Ao mesmo tempo, esses dois exemplos (somados às opiniões em torno dos ogãs, vistas acima) demonstram que os hipotéticos terreiros de Mara e de Rita perpetuariam as diferenças entre terreiros, ou as variações religiosas, e igualmente o estranhamento daqueles que, por qualquer razão, já estejam acostumados com outros modelos ou padrões rituais.

Em casa, longe da tutela imediata do/a dono/a de terreiro e suas entidades, médiuns e espíritos encontram-se mais "livres", por assim dizer, uma outra característica de situações liminoides.

[O] liminoide ainda é sentido como mais livre do que o liminal, uma questão de escolha, não de obrigação. O liminoide é como uma mercadoria - na verdade, é uma mercadoria, que se seleciona e se paga -, mais do que o liminal, que exige lealdade e está colado aos membros ou aos desejos dos membros em alguns altos grupos corporados. Um trabalha para o liminal, o outro brinca com o liminoide. (Turner 2012:251, grifo do autor)

Ao contrário de ser uma obrigação, as sessões em casa contrariam uma proibição, ou um forte desaconselhamento. As histórias de quem as faz alternam entre as 
manifestações inadvertidas dos espíritos e as invocações intencionais. Estas últimas, por mais arriscadas que possam vir a ser, são uma opção - igualmente tensa e poderosa. Afinal, esses momentos não são "simplesmente uma imagem invertida, máscara ou capa de atividade estrutural dos 'centros' do 'trabalho social produtivo"' (Turner 2012:228), mas sobretudo de potencial quebra de paradigmas, podendo resultar em separações, cisões, ou grandes mudanças - sobre as quais também escreve Turner ao repensar os modelos de análise de rituais de Van Gennep (Cavalcanti 2013; Dawsey 2005). A aura secreta que envolve esses rituais, para evitar exposição e conflitos que se quer adiados, é a mesma que lhes confere poder: o poder de transformar. Distante de mecanismos habituais de controle sobre si, médiuns e entes espirituais performam seus poderes em uma "brincadeira" muito séria, não somente por se construírem enquanto referências de axé (força espiritual), de conhecimento espiritual e de competência ritual, mas por reafirmarem suas respectivas autonomias diante da comunidade religiosa, sobretudo do seu pai ou mãe de santo.

\section{Considerações finais}

A religiosidade dos praticantes de Almas e Angola, assim como certamente acontece em outros grupos religiosos, não está restrita aos terreiros. Muitas vezes, as próprias entidades espirituais deslocam seus consultantes mais íntimos e seus médiuns, independentemente do consentimento prévio destes, para outros espaços nos quais estenderão suas consultas e trabalhos, longe das normas do terreiro (isto é, da dirigente e seus guias). O que se passa nas sessões em casa, por sua vez, pode acabar repercutindo nos terreiros: dúvidas, debates, enfrentamentos e mesmo cisões emergem daquilo que se aprendeu ou se experimentou alhures. Fórmulas, modelos, normas e explicações podem ser reforçadas, mas igualmente testadas ou substituídas. Assim, a um só tempo, as sessões em casa expõem: (1) o estatuto de sujeitos ou agentes sociais conferido aos espíritos pelo povo de santo, cujas vidas são marcadas por suas interferências nas mais diversas instâncias; (2) uma importante dinâmica de poder em torno de prestígio e legitimidade (geralmente por membros mais novos ou membros que foram expulsos de um terreiro) diante de líderes já reconhecidos pela comunidade religiosa; e (3) fatores significativos de transformação ritualística e, portanto, de variação intrarreligiosa, na medida em que as sessões em casa, uma prática tão difundida quanto polêmica entre adeptos de Almas e Angola, abrem espaço ao novo e ao diferente, que, por seu turno, substituirão certas normas, ou que se tornarão as novas normas a reger futuros terreiros.

De maneira geral, as sessões em casa são consideradas como perigosas por lideranças de terreiro, não apenas pela possibilidade de invasão de seres espirituais malignos e poderosos - os eguns e quiumbas -, mas também porque escapam ao poder de autoridade daqueles que controlam uma linhagem de filhos de santo e que se querem como referência espiritual inquestionável. Devo registrar que não há, em nível ana- 
lítico e tampouco para quem faz as sessões em casa, uma hierarquia entre os tipos de casa. Rita e Mara parecem fazer um uso pragmático dos discursos e das doutrinas que circulam pelos terreiros, mas isso não permite afirmar que haveria uma simples inversão da lógica dicotômica que, agora, centralizaria as sessões em casa e marginalizaria os terreiros. Como acredito ter demonstrado, tais centralidades não existem, tendo em vista que terreiro e casa oferecem práticas que não se excluem - afinal, as duas mulheres mantêm, com maior ou menor assiduidade, ambas as práticas ao longo de anos. $\mathrm{O}$ que se aprende nesses diferentes espaços poderá ou não se refletir nos modos com que se concebe e se faz a religião, mas as sessões em casa explicitam que aquilo que se passa nos terreiros e até mesmo as próprias lideranças não se configuram como referências religiosas absolutas para o povo de santo.

Por fim, é claro que Almas e Angola está "em processo de construção" como qualquer outra religião, afinal, nenhuma delas é estática ou se encontra acabada. Mas a perplexidade diante das diferenças deveria motivar questões de pesquisa, bem como delas afastar a busca (corriqueira entre religiosos) de se definir a "legítima" ou "verdadeira" modalidade ritualística/religiosa para Almas e Angola. Ao (per)seguir as práticas religiosas do povo de santo, é possível compreender mecanismos de mudanças que se dão a ver nos campos que geralmente escolhemos em pesquisas sobre religião: os templos. Indo para além dos terreiros, é possível explicar uma parte substancial das variações das quais eles mais frequentemente são o resultado, não a fonte. Como os estudos sobre religiões afro-brasileiras têm demonstrado ao longo do tempo, a variação e a heterogeneidade atravessam-nas desde suas respectivas constituições: cada casa é mesmo um caso (Barbosa Neto 2012). Entretanto, metodologicamente, é a ampliação do rastreamento das práticas religiosas, das trajetórias e dos agentes envolvidos - entes espirituais inclusos, como não poderia deixar de ser - que permitirá compreender os mecanismos que constituem e restituem essa sócio-lógica.

\section{Referências Bibliográficas}

ALVES, Daniela Bertti. (2007), Pelos Caminhos da Dor: Experiência de Doença e Narrativa em um Terreiro de Almas e Angola da Grande Florianópolis. Florianópolis: Trabalho de Conclusão de Curso em Ciências Sociais, UFSC.

BARBOSA NETO, Edgar. (2012), A máquina do mundo: Variações sobre o politeísmo em coletivos afro-brasileiros. Rio de Janeiro: Tese de Doutorado em Antropologia Social, MN/UFRJ.

BASTIDE, Roger. (1971 [1960]), As Religiões Africanas no Brasil - Contribuição a uma Sociologia das Interpenetrações das Civilizações. São Paulo: Pioneira - USP.

BIRMAN, Patricia. (1983), O Que é a Umbanda. São Paulo: Brasiliense.

BIRMAN, Patricia. (1995), "Transas e Transes: Sexo e gênero nos cultos afro-brasileiros, um sobrevôo". Estudos Feministas, vol. 13, no 2: 403-414.

CARDOSO, Vânia Zikán. (2007), "Narrar o mundo: estórias do 'povo-de-rua' e a narração do imprevisível”. Mana, no 2: 317-345.

CARDOSO, Vânia Zikán. (2009), "O espírito da performance”. Ilha: Revista de Antropologia, vol. 9, n⿳o 
1: $197-213$.

CARDOSO, Vânia Zikán. (2014), "Spirits and Stories in The Crossroads". In: D. Espírito Santo; R. Blanes (Orgs.). The Social Life of Spirits. Chicago: The University of Chicago Press.

CARDOSO, Vânia Zikán; HEAD, Scott Correll. (2013), "Encenações da descrença: a performance dos espíritos e a presentificação do real”. Revista de Antropologia, USP, vol. 56, nº 2: 257-289.

CAVALCANTI, Maria Laura Viveiros de Castro. (2013). "Drama, ritual e performance em Vitor Turner". Sociologia E Antropologia, vol. 3, no 6: 411-440.

DAWSEY, John C. (2005), "Victor Turner e a antropologia da experiência". Cadernos de Campo, no 13 : $163-76$.

DELATORRE, Franco. (2012), Santo de Casa Não Faz Milagre? Uma etnografia sobre rituais espirituais "caseiros" e espíritos. Florianópolis: Trabalho de Conclusão de Curso em Ciências Sociais, UFSC.

DELATORRE, Franco. (2014), "Trabalhar no Santo": Etnografia das práticas mediúnicas de um coletivo religioso "de matriz africana". Florianópolis: Dissertação de Mestrado em Antropologia Social, UFSC.

FARIAS, André Luiz. (2008), Fazer um Tata de Almas e Angola. Florianópolis: Trabalho de Conclusão de Curso em Ciências Sociais, UFSC.

GÓIS DANTAS, Beatriz. (1988), Vovó Nagô e Papai Branco: Usos e Abusos da África no Brasil. Rio de Janeiro: Graal Editores.

GOLDMAN, Marcio. (2011), "Cavalo dos Deuses. Roger Bastide e as transformações das religiões de matriz africana no Brasil”. Revista de Antropologia, USP, vol. 54, no 1: 407-432.

GOLDMAN, Marcio. (2012), "O dom e a iniciação revisitados: o dado e o feito em religiões de matriz africana no Brasil". Mana, vol. 18, no 2: 269-288.

HAYES, Kelly E. (2011), Holy Harlots. Femininity Sexuality And Black Magic In Brazil. Berkeley: University of California Press.

HOBSBAWM, Eric; RANGER, Terence (orgs.). (1984), A invenção das tradições. Rio de Janeiro: Paz e Terra.

LEITE, Ilka Boaventura; PINHEIRO, Thabata J. B. (2017), Territórios do Axé: religiões de matriz africana em Florianópolis e municípios vizinhos. Núcleo de Estudos de Identidades e Relações Interétnicas (NUER-UFSC). Florianópolis: Editora da UFSC.

MARTINS, Giovani. (2006), Ritual de Almas e Angola em Santa Catarina. Florianópolis: Gráfica Baía dos Limões.

MARTINS, Giovani. (2010), Ritual de Almas e Angola: a Umbanda Catarinense. Florianópolis: Ed. do Autor, $2^{-}$ed.

MÜTZENBERG, Bruno Vinícius; WEBER, Thiago Linhares. (2013), "Retirada do corte na Umbanda de Almas e Angola: Kardequisação ou Ambientalismo?". Revista Brasileira de História das Religiões, no 15: 1-16. Disponível em: http://www.dhi.uem.br/gtreligiao/pub.html. Acesso em: 15/12/2018.

NÓBREGA, Priscila Brandão Martins da. (2004), Cortar para o Santo: o lugar do sacrifício animal em Almas e Angola. Florianópolis: Trabalho de Conclusão de Curso em Ciências Sociais, UFSC.

OLIVEIRA, Bianca Ferreira. (2012), Pessoa, jocosidade e moral a partir de uma família de santo de Almas e Angola. Florianópolis: Dissertação de Mestrado em Antropologia Social, UFSC.

OPIPARI, Carmen. (2009), O candomblé: imagens em movimento. São Paulo: Edusp.

PIAULT, Marc. (2003), "Crer e Saber: de caminho para uma antropologia pragmática”. In: P. Birman (org.). Religião e Espaço Público. São Paulo: Attar Editorial.

RABELO, Miriam. (2014), Enredos, Feituras e Modos de Cuidado: dimensões da vida e da convivência no candomblé. Salvador: EDUFBA.

SANSI, Roger. (2013), "We worship nature”. In: D. Espírito Santo; N. Tassi (Orgs.). Making Spirits. Materiality and transcendence in contemporary religions. London: I. B. Tauris.

SEGATO, Rita Laura. (1995), Santos e Daimones: O Politeísmo Afro-Brasileiro e A Tradição Arquetipal. Brasília: Editora da Universidade de Brasília.

SILVA, Vagner Gonçalves da. (2000), O antropólogo e sua magia. São Paulo: EdUSP.

TRAMONTE, Cristiana. (2001), Com a Bandeira de Oxalá! Trajetória, práticas e concepções das religiões 
afro-brasileiras na Grande Florianópolis. Florianópolis: Editora Lunardelli.

TURNER, Victor. (2012), "Liminal ao Liminoide: em brincadeira, fluxo e ritual. Um ensaio de simbologia comparativa”. Mediações, vol. 17, nº 2: 214-257.

VELHO, Gilberto. (1994), Projeto e metamorfose: Antropologia das sociedades complexas. Rio de Janeiro: Zahar.

WEBER, Thiago Linhares. (2011), "Mudanças no ritual almas e angola: os novos paradigmas de Giovani Martins". Revista Brasileira de História das Religiões, vol. III, no 9: 1-11. Disponível em: http://www. dhi.uem.br/gtreligiao/pub.html. Acesso em: 12/2018.

\section{Entrevistas}

Entrevista com Mara, Florianópolis, janeiro de 2011.

Entrevista com Rita, Florianópolis, janeiro de 2011. 


\section{Anexo}

Imagem 1: Congá de Rita

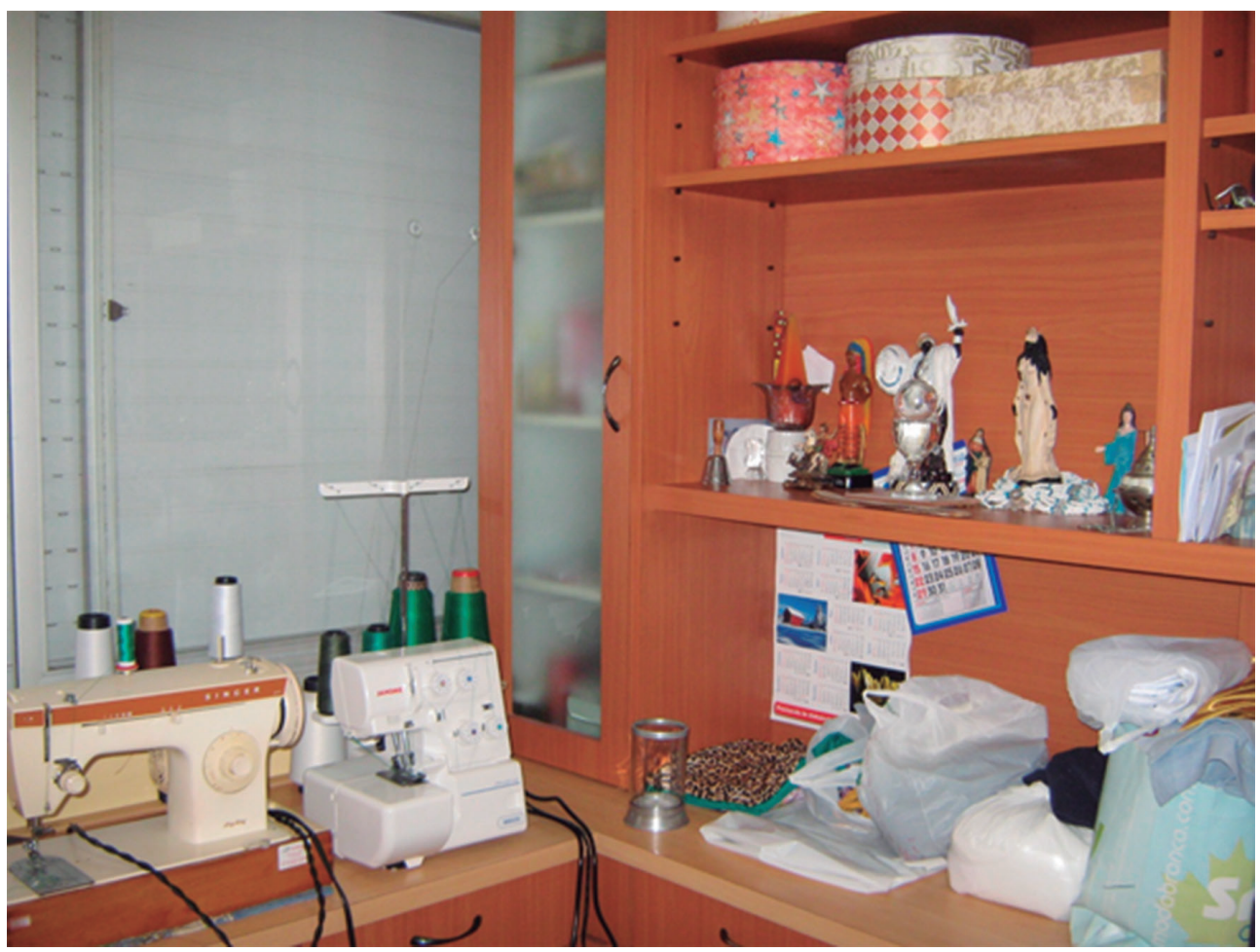

Foto: Franco Delatorre, em 2011. 
Imagem 2: Congá de Rita (aproximado)

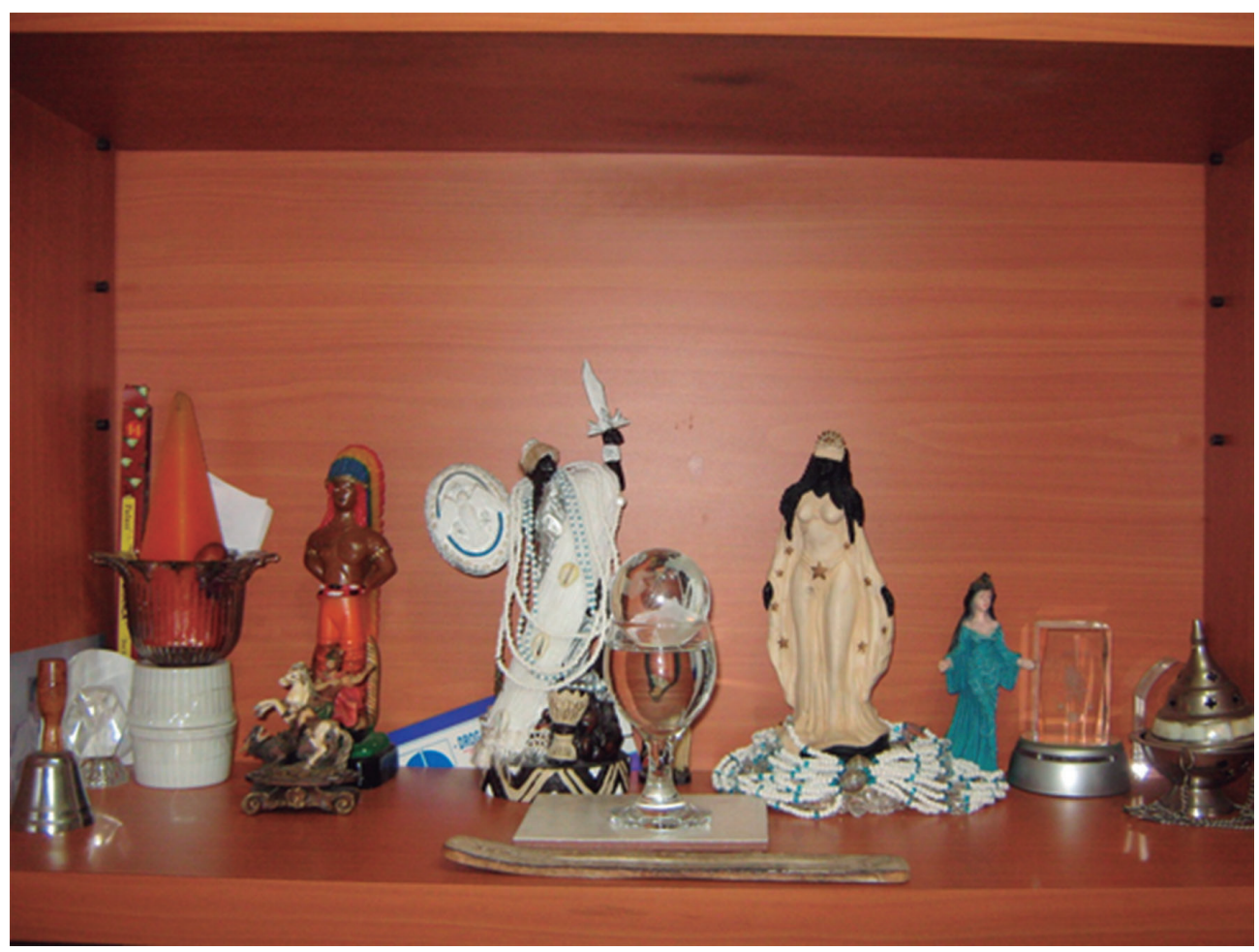

Foto: Franco Delatorre, em 2011. 
Imagem 3: Congá de Mara (parcial)

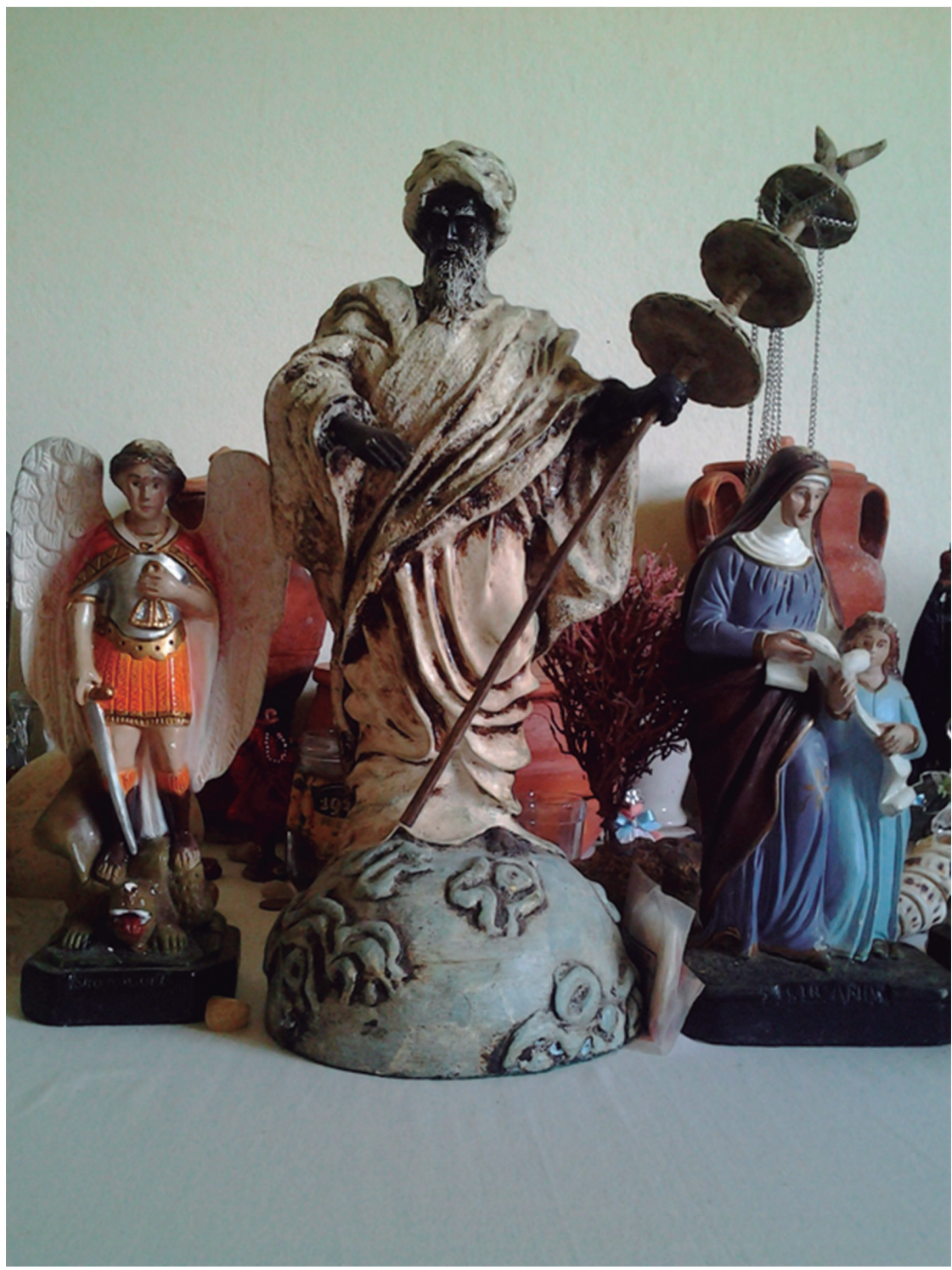

Foto: Franco Delatorre, em 2011. 


\section{Notas}

1 Observo que restringirei o uso de itálico para expressões utilizadas pelos/as interlocutores/as (entes espirituais inclusos) ao menos à primeira vez que figurarem no texto.

2 Da parceria entre o Instituto do Patrimônio Histórico e Artístico Nacional (IPHAN) e o Núcleo de Estudos de Identidade e Relações Interétnicas (NUER-UFSC), foi realizado, em 2017, o projeto Territórios do Axé: religiões de matriz africana em Florianópolis e municípios vizinhos, visando ao levantamento e à análise de dados referentes a tais práticas religiosas na referida região, que até então careciam de sistematização e atualizações. A obra aqui citada cobre dados preliminares; outras análises e estatísticas ainda aguardam publicação.

3 Entidades respectivamente masculinas e femininas, que teriam ocupado um lugar socialmente marginalizado foram prostitutas, gigolôs, malfeitores, ciganas, etc.

4 Há várias maneiras pelas quais as entidades se referem às pessoas em quem incorporam, por exemplo: burro/a, cavalo, aparelho, filho/a, menina/o, etc.

5 O referido casal de orixás é necessariamente de gêneros opostos, sendo que, em geral, os orixás são os principais ou de frente para os homens e as orixás são de frente para as mulheres - uma regra que possui exceções e que frequentemente se mostra oposta para pessoas homossexuais. A quantidade de entes espirituais que acompanham uma pessoa pode ser maior (pode haver mais entidades de cada linha) e se complexifica ao longo do tempo, quando o adepto passa a conhecer seus outros orixás além dos principais (orixás de cabeça).

6 O termo assistência refere a um só tempo as pessoas visitantes e o espaço ocupado por elas, que vão para assistir as sessões enquanto aguardam pelo momento das consultas com as entidades, no fim da noite.

7 Camarinha é também o nome do espaço no qual estes rituais ocorrem; na maioria dos terreiros de Almas e Angola, a(s) Camarinha(s) é um espaço estreito, localizado nas laterais do congá.

8 As coroas são "apelidadas" indicando o ritual pelo qual passou o médium; assim, há a Coroa de Bori, a Coroa de Babalorixá (Pai de Santo) ou de Ialorixá (Mãe de Santo), e a Coroa de Tata para quem há 21 anos fez sua Coroa de Pai ou de Mãe de Santo.

9 Todos os nomes utilizados são fictícios.

10 Não há como aprofundar neste espaço as complexas noções de desenvolvimento, mas cabe resumi-las em dois sentidos principais. Um deles está relacionado aos valores morais presentes na religião, cujas influências do kardecismo envolvem ideias de reencarnação, iluminação, doutrinação e caridade para que cada pessoa cumpra sua missão e que evolua espiritualmente. É nesse sentido que se diz que a pessoa trabalha a si mesma no santo, para desenvolver-se. O outro sentido lembra o que escreve Goldman (2012) sobre a pessoa no candomblé, mas a referida "lapidação", aqui, se dá em torno dos dons mediúnicos - e há terreiros de Almas e Angola que reservam um dia na semana para este fim nas chamadas sessões de desenvolvimento (ver Oliveira 2012; Delatorre 2014).

11 Escolhi manter a primeira expressão citada por ser a utilizada pelas minhas interlocutoras.

12 Também abordam as autodesignações Nóbrega (2005), Alves (2008), Farias (2008) e Oliveira (2012).

13 Por "sacrifício de angolistas brancas", o autor refere-se à imolação ritual das aves popularmente conhecidas como galinhas-d'angola, coquém, capote, entre outros nomes.

14 As regras quanto aos rituais durante a Quaresma são exemplares do tema das variações no caso de Almas e Angola. Não há espaço para aprofundar aqui esse tópico, que é mais detalhado do que os dois exemplos que seguem. Há terreiros que, nessa época, só permitem trabalhos com povo de rua, enquanto noutros essa linha é a única vetada; há terreiros em que não se recebe orixás, pois alega-se que estes não atenderiam às invocações durante a Quaresma, diferentemente de outros terreiros nos quais só os orixás se fazem presentes; etc.

15 Explorar tais questões com profundidade excede as intenções deste artigo. Agradeço a um/a parecerista que atentou à importância de se pensar as relações familiares sobre as práticas aqui abordadas, realizadas em um ambiente íntimo, compartilhado e mesmo heterogêneo (inclusive religiosamente, como na casa de Mara).

16 Percebe-se, de acordo com as imagens no Anexo, que o Oxalá do congá à mesa de Mara é a imagem de um homem negro, e não Jesus Cristo, como nos congás dos terreiros de Almas e Angola. Rita não disse se também substituiria as imagens católicas no congá caso viesse a abrir um terreiro, mas seu Oxaguiã e sua Iemanjá são "africanos" no altar em sua sala de costuras (conferir as duas primeiras imagens).

Submetido em: 14/12/2018 Aceito em: 01/08/2019 
Franco Delatorre* (francogoodenough@hotmail.com)

* Doutorando em Antropologia Social na Universidade Federal de Santa Catarina (UFSC), Florianópolis, SC, Brasil; Mestre em Antropologia Social pela UFSC. 


\section{Resumo:}

\section{Sessões em Casa: práticas religiosas e variação em Almas e Angola}

Neste artigo, abordo as variações litúrgicas/religiosas relativas à Almas e Angola, religião afro-brasileira bastante difundida em Santa Catarina. Não é minha intenção explorar os diversos fatores que contribuem para tais variaçóes entre práticas religiosas homônimas, tampouco detalhar as formas com que as/os dirigentes particularizam suas práticas em seus respectivos terreiros. Numa outra direção, argumento que, para compreender aquilo que se passa nos terreiros, é preciso sair deles e seguir os próprios adeptos e seus espíritos em suas práticas religiosas "paralelas" - nesse sentido, minha etnografia concentra-se nas chamadas sessões em casa.

Palavras-chave: religião afro-brasileira; Almas e Angola; espíritos; variação; transe

\section{Abstract:}

\section{Sessões em Casa (Homemade Rituals): religious practices and variation in Almas and Angola}

In this article, I discuss the liturgical/religious variations related to Almas e Angola, an afro-brazilian religion widespread in Santa Catarina, southern Brazil. It is not my intention to explore the various factors that contribute to such variations between homonymous religious practices, nor to detail the ways in which the leaders particularize their practices in their respective terreiros (temples). In another direction, I argue that, in order to understand what is going on in the terreiros, it is necessary to leave them and follow adepts and their spirits in their "parallel" religious practices - thus, my ethnography focuses on the so-called sessões em casa (homemade rituals).

Keywords: Afro-Brazilian religion; Almas e Angola; spirits; variation; trance 